УДК 338. 48 (477)

JEL L 23 L 83

DOI 10.31375/2226-1915-2021-3-129-144

СОЦИОЛОГИЧЕСКИЙ АСПЕКТ ОРГАНИЗАЦИИ ДОСУГА В УКРАИНЕ

\author{
О.В. Назаренко \\ к.э.н, доцент, \\ доцент кафедры туристического \\ и гостинично-ресторанного бизнеса \\ Одесский национальный экономический \\ университет, Одесса, Украина
}

Аннотация. Актуальность данного исследования обусловлена тем, что одной из наиболее распространенных форм отдыха населения является туризм, который развивается более быстрыми темпами, чем другие виды аналогичных услуг. Украина, перестраивая свою экономику на рыночных принциипах, включается в мировой туристический проиесс, о чем свидетельствует рост туристических потоков и нарашивание объемов деятельности реформированной индустрии туризма. В нашей стране развивается законодательная и нормативная база (законь Украины «О туризме», «О курортах» и другие законодательные акты, указы Президента и постановления Кабинета Министров), строится по мировым стандартам национальная индустрия туризма (Государственные программы развития туризма), которые позволяют внедрять государственную туристическую политику и влиять на формирование национального туристического рынка. Международное признание Украины как туристического государства зафиксировано принятием ее в состав Всемирной Туристической Организачии (ВTO), которая насчитывает сейчас 158 стран-членов, и избранием первой среди стран СНГ в состав Исполнительного Совета ВТО.

Включение Украины в мировой туристический процесс, развитие индустрии туризма и деятельности субъектов туристического рынка требуют научного обоснова ния направлений развития и проблем геопространственной организачии национального туризма на основе обобщения мировых тенденций и их научного осмысления.

Ключевые слова: рекреация, туризм, услуги, туристическая анимачия, досуг, факторы развития туризма, инфраструктура.
УДК 338. 48 (477)

JEL L 23 L 83

DOI 10.31375/2226-1915-2021-3-129-144

СОЩІОЛОГІЧНИЙ АСПЕКТ ОРГАНІЗАЦІЇ ДОЗВІЛЛЯ В УКРАЇНІ

\author{
О.В. Назаренко \\ к.е.н, доцент, \\ доцент кафедри туристичного \\ та готельно-ресторанного бізнеса \\ Одеський національний економічний університет, \\ Одеса, Украӥна
}

Анотація. Актуальність даного дослідження обумовлена тим, щуо однією з найбільш поширених форм відпочинку населення $\epsilon$ туризм, який розвивається більш швидкими темпами, ніж інші види аналогічних послуг. Украӥна, перебудовуючи свою економіку на ринкових засадах, включається у світовий туристичний прочес, про щзо свідчить зростання туристичних потоків $і$ нарощування обсягів діяльності реформованої індустріі туризму. У нашій країні розвивається законодавча і нормативна база (закони України «Про туризм», «Про курорти» та інші законодавчі акти, укази Президента та постанови Кабінету Міністрів), позабудовується за світовими стандартами начіональна індустрія туризму (Державні програми розвитку туризму), які дозволяють впроваджувати державну туристичну політику і впливати на формування начіонального туристичного ринку. Міжнародне визнання України як туристичної держсави зафіксоване прийняттям іï до складу Всесвітньої Туристичної Організачї (ВТО), яка нараховуе зараз 158 крайнчленів, та обранням першою серед країн СНД до Виконавчої Ради ВТО.

Включення України у світовий туристичний процес, розбудова індустрії туризму та діяльність суб'єктів туристичного ринку потребують наукового обтрунтування напрямків розвитку та проблем геопросторовоі організачії начіонального туризму на основі узагальнення світових тендениій та їх наукового осмислення.

Ключові слова: рекреачія, туризм, послуги, туристична анімачія, дозвілля, фактори розвитку туризму, інфраструктура.

(C) Назаренко O.B., 2021 
UDC 338. 48 (477)

JEL L 23 L 83

DOI 10.31375/2226-1915-2021-3-129-144

\title{
SOCIOLOGICAL ASPECT OF ORGANIZING LEISURE TIME IN UKRAINE
}

\author{
Olga V. Nazarenko \\ CEcon, docent, docent \\ of the Department of «Tourism and Hotel and Restaurant Business» \\ olga.nazarenko.od@gmail.com
}

Odessa National Economic University, Odessa, Ukraine

\begin{abstract}
The relevance of this study is due to the fact that one of the most common forms of recreation for the population is tourism, which is developing at a faster pace than other types of similar services.

Ukraine, restructuring its economy on market principles, is included in the global tourism process, as evidenced by the growth of tourist flows and the increase in the volume of activities of the reformed tourism industry. In our country, the legislative and regulatory framework is developing (the laws of Ukraine "On Tourism», "On Resorts» and other legislative acts, decrees of the President and resolutions of the Cabinet of Ministers), the national tourism industry is being built according to world standards (State programs for the development of tourism), which make it possible to implement state tourism policy and influence the formation of the national tourism market. The international recognition of Ukraine as a tourist state is fixed by its admission to the World Tourism Organization (WTO), which now has 158 member countries, and by the election of the first among the CIS countries to the Executive Council of the WTO.

The inclusion of Ukraine in the global tourism process, the development of the tourism industry and the activities of the subjects of the tourism market require scientific substantiation of the directions of development and problems of the geospatial organization of national tourism on the basis of generalizing world trends and their scientific understanding.

Keywords: recreation, tourism, services, tourist animation, leisure, factors of tourism development, infrastructure.

Постановка проблеми. Сучасна складна економічна ситуація у світі в цілому та в Україні зокрема зумовлює особливу актуальність дослідження проблем досягнення сталого соціально-економічного розвитку країни, в якості одного з реальних чинників якого в сучасному світі розглядається рекреація і туризм як сфери надзвичайно важливої соціально-економічної діяльності. Наслідками глобальної економічної кризи $\epsilon$ спад виробництва, скорочення робочих місць, інфляція. У результаті бюджет держави недоотримує значні кошти, а рекреація і туризм не потре-

бують значних інвестицій та порівняно 3 іншими галузями господарства досить швидко розвиваються, що дасть змогу за невеликий термін створити нові робочі місця та суттєво наповнити бюджет. Рекреація і туризм стимулюють розвиток інших галузей, таких як харчова та легка промисловість, будівельна галузь, торгівля, транспорт і зв'язок та ін.

Важливим соціальним аспектом розвитку рекреації і туризму є потужний вплив туристично-рекреаційної діяльності на людський розвиток, забезпечення оздоровлення та відпочинку населення, проведення зміс-
\end{abstract}


товного дозвілля. Україна має величезний потенціал для розвитку рекреації і туризму, представлений різноманітними туристично-рекреаційними ресурсами. Водночас актуальним виступає реалізація цього потенціалу, його використання задля розширення можливостей людського розвитку, вирішення соціальних проб-лем населення.

Отже, поглиблення теоретикометодологічних засад дослідження соціальних аспектів розвитку рекреації і туризму як значущого сегменту світового господарства, визначення заходів щодо удосконалення функціонування та перспектив розвитку туристично-рекреаційної індустрії, підвищення соціальної ефективності рекреації і туризму в Україні і світі $\epsilon$ однією 3 найважливіших актуальних проблем сучасної економічної науки.

Огляд останніх досліджень та публікацій. Рекреація і туризм - найдинамічніщі галузі у світі, чинники економічного та культурного розвитку, захисту навколишнього середовища та історико-культурної спадщини, міжнародного взаєморозуміння та миру. Сьогоднішнім завданням $\epsilon$ збереження і примноження туристично-рекреаційного потенціалу нашої країни, нагромадженого століттями, поставити і заставити працювати на його користь нові організаційно-економічні механізми, що відкриваються в сучасному світі.

Проблеми рекреації і туризму знаходяться в центрі уваги економічної та економіко-географічної науки. Найбільш глибоко та системно розглядаються особливості територіальної локалізації рекреаційних ресурсів, рекреаційна місткість та природнорекреаційний потенціал територій, розвиток туристично-рекреаційних комплексів, дослідження рекреації i туризму як сфери ринкових відносин, проблеми розвитку рекреації і туризму, зокрема як видів діяльності. Удосконалюються методи забезпечення об'єктами туристично-рекреаційної інфраструктури, надання туристичнорекреаційних послуг населенню, питання розробки і реалізації державної та регіональної політики щодо розвитку рекреації і туризму, теоретичні аспекти функціонування міжнародного туризму в роботах цілого ряду вчених економ-географів та економістів, таких як Багров М.В., Веденін Ю.А., Гідбут О.В., Твердохлєбов І.Т., Долішній М.I., Нудельман М.C., Пістун М.Ф., Стеченко Д.М., Шаблій O.I., Руденко В.П., Крачило М.П., Генсірук С.А., Котляров С.А., Квартальнов В.А., Свдокименко В.К., Жильцов Є.Н., Якобсон Л.І., Любіцева О.О., Куценко В.І., Новіков В.М., Мельник А.Ф., Паціорковський В.В., Кравців В.С., Пітюренко Ю.І., Герасимчук 3.В., Фоменко Н.В., Мальська М.П., Худо В.В., Федорченко В.К. та ін. $[3-7 ; 16]$.

Підтвердженням цього $є$ фіксація в Законі України «Про туризм» положення про те, що туризм є пріоритетним напрямом розвитку економіки та культури нашої країни. Проте дослідження соціальних аспектів розвитку рекреації і туризму, як значущого сегменту світового господарства, визначення їх впливу на економіку країни і суспільний розвиток, підвищення соціальної ефективності рекреації і туризму в Україні та світі потребують більш повного наукового обгрунтування.

Задача дослідження. Поглиблення теоретико-методологічних за- 
сад дослідження соціальних аспектів розвитку рекреації і туризму як значущого сегменту господарства України.

Основний матеріал дослідження. Досягнення поставленої мети передбачає вирішення таких завдань: 3'ясування сутності туризму, визначення особливостей туристично-рекреаційної діяльності та іï результатів, узагальнення основних напрямів впливу туризму на суспільний розвиток, обгрунтування пріоритетів підвищення соціальної ефективності туризму в Україні та світі в цілому.

Понятійно-термінологічний апарат, який використовується в туристично-рекреаційних дослідженнях, характеризується відсутністю чітко визначеної системи дефініцій, а також їх багатозначністю та різноманіттям. Це пояснюється тим, що, поперше, наукові пошуки, які ведуться у цій галузі $є$ динамічними, а подруге, дослідження здійснюються в рамках декількох спеціальностей: рекреаційна географія, економіка рекреації та туризму, соціологія туризму, освіта (в рамках професійної підготовки кадрів для галузі туризму), туристичний менеджмент та маркетинг тощо. Під рекреаційними ресурсами розуміють частину туристських ресурсів, яка являє собою природні та антропогенні геосистеми, тіла та явища природи, артефакти, що володіють комфортними властивостями i споживною вартістю для рекреаційної діяльності і можуть бути використані дня організації відпочинку та оздоровлення певного контингенту людей у фіксований час 3 допомогою існуючої технології та наявних матеріальних можливостей. В свою чергу, поняття туристичні ресурси охоплює сукупність природних і соціальнокультурних комплексів та їх елементів, що сприяють задоволенню фізіологічних та соціальних потреб людини, відновленню ¥іi працездатності і які при сучасній та перспективній структурі рекреаційних потреб і техніко-економічних можливостях, використовуються для прямого й опосередкованого споживання та виробництва туристичного продукту.

Враховуючи природну, соціальну та історико-культурну складові у визначеннях рекреаційних та туристичних ресурсів, орієнтацію на споживання і задоволення потреб людей (туристів) найчастіше ці поняття вважають близькими за значеннями $\mathrm{i}$ об'єднують єдиним поняттям - туристично-рекреаційний комплекс.

Найбільш важливими кількісними та якісними характеристиками туристичних ресурсів $є$ :

- обсяг запасів (дебіт джерел мінеральних вод, екскурсійний потенціал туристичних центрів і маршрутів), необхідний для визначення потенційної ємності туристичних комплексів, рівня освоєння, оптимізації техногенного й антропогенного навантаження;

- площа поширення (розміри водоносних горизонтів, пляжів, лісів, площа територій зі стійким сніговим покривом), яка дозволяє визначити потенційні рекреаційні території, встановити межі санітарної охорони;

- період можливої експлуатації (тривалість сприятливого погоднокліматичного періоду, купального чи лижного сезону), який визначає сезонність рекреаційних процесів і ритмічність туристичних потоків;

- територіальна зосередженість у місцях виникнення чи поширення, 
яка обумовлює тяжіння туристичної інфраструктури і туристичних потоків до місць їх концентрації;

- порівняно низька капіталомісткість і невисока вартість експлуатаційних затрат, що дозволяє досить швидко створювати інфраструктуру й отримувати соціальний та економічний ефект, а також самостійно використовувати окремі види ресурсів;

- багаторазовість використання при дотриманні норм раціонального природокористування i проведення заходів із рекультивації та благоустрою;

- універсальність, яка дозволяє використовувати один і той же ресурс для організації різних видів рекреаційно-туристичної діяльності;

- масовість, унікальність, інформативність і доступність, від яких залежить потужність туристичних потоків і можливість створення інфраструктури;

- соціальність - незалежно від походження і використання, туристичні ресурси характеризуються «цільовим призначенням» - покращання соціальних параметрів у суспільстві.

Освоєння туристично-рекреаційних ресурсів - це найважливіший пріоритет економіки оскільки саме вони виступають основою діяльності туристично-рекреаційного комплексу. Саме ресурси є базовою основою для формування туристично-рекреаційного комплексу. Їх специфіка полягає у тому, що вони не підлягають перевезенню для того, щоб використовувати їх для виробництва туристичного продукту. Це й обумовлює їх важливе значення 3 точки зору розвитку регіонального туризму, оскільки регіональні ресурси відображають стан конкретної території регіону і частіше всього обмежені, а здатність регіону задовольняти потреби туристів, визначається складом і станом ресурсів та факторів для розвитку туризму на цій території.

Головною метою функціонування туристично-рекреаційного комплексу, наприклад, всієї країни є соціально-економічний розвиток регіону через упорядкування й забезпечення розвитку туристично-рекреаційної галузі на території міста, адміністративного району або області як пріоритетного виду економічної діяльності.

Туризм як товар реалізується у формі послуг. Послуга туризму, як i послуга взагалі, $є$ дією певної споживчої вартості, що виражається в корисному ефекті, що задовольняє ту чи іншу людську потребу. При цьому послуга може бути надана або річчю, тобто за допомогою товару, або у процесі функціонування живої праці. Зазначені два способи виробництва послуг обумовлюють i два види самих послуг: матеріальні (виробничі), опосередковані з річчю, і нематеріальні (невиробничі), не пов'язані 3 матеріальними продуктами, виробництво яких невіддільне від їх споживання. Туристична послуга як «невидимий» товар має низку особливостей: нематеріальний характер; нездатність до накопичення; виробництво i споживання відбуваються одночасно; споживач бере участь у процесі виробництва туристичної послуги. Тур представляє собою комплекс різних послуг (розміщення, харчування, транспортні послуги, побутові, туристські, екскурсійні та інші), об'єднаних на основі головної мети подорожі і надаються на певному маршруті у визначений термін. Крім по- 
слуг, туристи можуть купувати товари туристського призначення. Сукупність послуг і товарів туристичного призначення утворює поняття «туристичний продукт».

Тур продукт включає:

- тури, об'єднані за цілеспрямованістю;

- туристично-екскурсійні послуги різних видів;

- товари туристично-сувенірного призначення.

Туристичні послуги, запропоновані в ролі товару на світовому ринку, досить різноманітні. До них відносяться:

- послуги 3 розміщення туристів;

- послуги по переміщенню туристів до країни призначення i по країні різними видами пасажирського транспорту;

- послуги по забезпеченню туристів харчуванням;

- послуги, спрямовані на задоволення культурних потреб туристів;

- послуги, спрямовані на задоволення ділових інтересів туристів; ЄМств;

- послуги торгових підпри-

- послуги 3 оформлення документації.

Туристу можуть бути надані або певні види послуг по його вибору, або повний комплекс послуг. Повний комплекс послуг може надаватися шляхом продажу так званих інклюзив-турів (пекідж-турів).

У світовій практиці дозвілля, використовуючи туристичний сегмент, поширюється анімаційна діяльність у різних якостях і формах.

Найчастіше іiі пропонують як одну iз туристичних послуг. Таким чином, еволюція поглядів на аніма- ційну складову туризму дає змогу зробити висновок, що основними завданнями в організації туристичного дозвілля є: подолання розмежування соціальних суб'єктів, розвиток їх самоактивності, посилення духовної складової у формах дозвілля, що можливе за допомогою анімаційної діяльності.

Туристична анімація - це різновид туристичної діяльності, здійснюваної на туристичному підприємстві (туркомплексі, отеленні), на транспортному засобі (круїзному теплоході, поїзді, автобусі й т.д.) або в місці перебування туристів (на міській площі, у театрі або парку міста й т.д.), що утягує туристів у різноманітні заходи через участь у спеціально розроблених програмах дозвілля. Інакше кажучи, туристична анімація - це туристична послуга, при наданні якої турист утягується в активну дію.

У типології анімації важливе місце посідає готельна, оскільки застосування цього виду анімації в разі ii успішності посилює позитивний економічний ефект діяльності готелю. Вона спрямована на:

- підвищення якості, розмаїтості і привабливості готельного продукту і туристичних послуг;

- підвищення якості обслуговування гостей;

- збільшення кількості постійних гостей i попиту на готельний продукт за рахунок повторних звернень;

- збільшення навантаження й підвищення ефективності використання матеріально-технічної бази готельного підприємства; 
- створення позитивного іміджу і репутації організації;

- зростанні прибутковості та рентабельності діяльності організації в цілому.

Для ефективної реалізації готельної анімації потрібні такі складники:

1) концепція готельної анімаційної діяльності 3 набором типових анімаційних програм i методик їx адаптації до реальних груп i персоналій;

2) кваліфіковані аніматори, які здатні втілити концепцію, програми і методики у життя, а також персонал, задіяний у процесі обслуговування гостей;

3) матеріально-технічна база для проведення спортивно-оздоровчих і розважальних занять.

Сьогодні у світі розвинена інфраструктура ринку розважальних послуг - сукупність підприємств, систем і технологій, що виконують певні функції 3 надання розважальних послуг і створюють умови для його функціонування.

У туризмі та індустрії готельного бізнесу під підприємствами розуміють план проведення розважальних заходів чи програми, які об'єднані загальним задумом та метою. Анімаційні програми для різного віку та соціального статусу туристів розробляються задля урізноманітнення культурно-дозвільних послуг, які надаються додатково підприємствами готельно-ресторанної і туристичної сфери.

Анімаційна програма має певну сюжетну лінію, сценарій, дійових осіб представлених аніматорами, музичний супровід. В залежності від мети та спрямованості анімаційних програм анімація буває спортивна, спортивно-оздоровча, спортивно-пізнавальна, культурно-пізнавальна, пригодницько-ігрова, творча та видовищно-розважальна.

Основні завдання анімаційної служби полягають у створенні комфортної, дружньої та гостинної атмосфери в закладі, задоволенні потреб відпочиваючих у духовному, емоційному та фізичному розвитку, формуванні умов для приємної комунікації і проведення дозвілля.

Керівником анімаційної діяльності є менеджер анімаційної служби, функціональні обов'язки якого зводяться до розробки комплексних анімаційних програм, виявленні та задоволенні соціально-культурних потреб різних груп туристів, управлінні економічним механізмом організації анімаційної діяльності на підприємстві та колективом анімаційної служби.

Шеф-аніматори керують конкретними анімаційними програмами в комплексному анімаційному процесі.

Для того, щоб підтримувати високу якість обслуговування туристичному закладу потрібні досвідчені, талановиті, чесні і доброзичливі аніматори, які отримують задоволення від своєї роботи. До аніматорів висуваються наступні вимоги:

- високий рівень комунікаційних навиків та знання іноземних мов;

- привітність та ввічливість, чесність і дисциплінованість, вміння створювати дружню та радісну атмосферу;

- здатність працювати в команді та виконувати поставлені завдання;

- творчі та артистичні задатки особистості; 
- стресостійкість тощо.

Задоволеність туриста середовищем гостинності - це якісна оцінка його стану після здійснення подорожі (відпочинку), характеристика повноти досягнення свідомих і підсвідомих цілей подорожі із знижкою на його особисте розуміння і сприйняття навколишнього світу, цінності життя, безпеки, якості обслуговування і гостинності.

Основними принципами дозвіллєвого обслуговування в туристичних комплексах $є$ : індивідуальний підхід, комплексність у організації дозвіллєвих заходів, систематичність проведення дозвіллєвих заходів та їх цілеспрямованість, свобода вибору та добровільність участі, театралізація. Синтез усіх видів мистецтв.

Різноманітність форм дозвіллєвої діяльності є запорукою подальшого успішного функціонування всього туристичного комплексу. Дозвіллєва програма повинна відповідати загальній стратегії розвитку туристичного комплексу.

Дозвіллєві програми в туристичних комплексах можна умовно класифікувати за такими ознаками:

- місцем проведення - паркові, клубні, готельні;

- віком учасників - дитячі, юнацькі, молодіжні, для дорослих, пенсіонерів;

- радіусом діï - районні, місцеві, муніципальні, міжнародні

Загальновизнаною вважається класифікація дозвіллєвих програм за напрямами діяльності:

- рекреаційно-оздоровчі (дискотеки, танцювальні вечори, розважальні програми та вечірні шоу, карнавали, рибальство, ігрові конкурси, спортивні змагання);

136
- спортивні (мандрівки, змагання, велоспорт, плавання, екскурсії, подорожі);

- культурно-мистецькі (спектаклі, виставки, концерти, вернісажі, фольклорні акції, художні програми, відвідування музеїв, виставок, галерей);

- просвітні (лекції, зайняття за інтересами, зустрічі, інтелектуальні ігри, вікторини, фестивалі).

Щодо відвідувачів туристичних комплексів, їх класифікація здійснюється за різними ознаками:

- за віком (діти, підлітки, молодь, дорослі, люди похилого та «золотого» віку),

- за статтю (чоловіки та жінки), за релігійними поглядами (невіруючі, православні, католики, мусульмани),

- за професійною приналежністю (військові, вчителі, художники, архітектори) та ін.

Аніматори повинні знати специфіку сімейного дозвілля, особливості його розвитку, популярні форми дозвіллєвої діяльності. Тому що значну кількість серед відвідувачів туристичних комплексів складають сім'ї.

У готелях відпочиває велика кількість молоді (школярі, студенти, спортивні команди). Це дуже активний сегмент, і головне для них - провести свій відпочинок максимально весело і цікаво. I анімаційна команда, проводячи свої заходи, у першу чергу звертає увагу саме на цю категорію туристів.

Молодих людей можна розділити на дві вікові категорії: від 18 до 24 і від 25 до 34 років. Ці категорії мають значної рухової здатністю i впливом, так як вони найбільш численні. Оскільки вони являють собою велику групу людей, можна визна- 
чити комплексні тенденції в даному сегменті - щодо пізнє заміжжя, поява в сім'ї першої дитини, невелике домашне господарство, важливість кар'єри для обох дорослих членів сім'ї.

Враховуючи такі розбіжності серед відпочиваючих, можна правильно підібрати форми роботи 3 ними, найбільш продуктивно поєднувати активний і пасивний відпочинок, зробити дозвілля цікавим і повноцінним.

$\mathrm{y}$ міжсезоння і зимовий період готель відвідують люди похилого віку, пенсіонери. Для них це найсприятливіший час, коли сонце вже не пече так сильно, як влітку. Для цієї категорії туристів анімаційна програма пропонує різного роду інтелектуальні ігри та нескладні спортивні змагання.

Спостерігається тенденція зростання груп людей похилого віку (60-65 років і старше). Ці групи іноді називають ринком людей зрілого віку, пенсійного віку, похилого або «третього віку». Цей сегмент ринку повинен бути вивчений менеджерами анімації, оскільки він $є$ поступово зрос-

таючим і не менш важливим, ніж інші вікові сегменти туристичного ринку.

Треба пам'ятати, що пенсіонери, хоча й своєму розпорядженні велику кількість вільного часу, який вони могли б витратити на подорожі, обмежені в коштах. Деякі пенсіонери продовжують працювати і витрачати кошти на подорожі. Дані вікові групи людей можуть стати споживачами недорогих товарів i послуг, тому доцільно пропонувати ім спеціальні пільги, знижки на розміщення та харчування, пільгові тарифи на транспорті.
Зрілі люди не люблять, коли їм нагадують про їх вік. Отже, програми повинні враховувати цей фактор. Їхній спосіб життя дозволяє їм подорожувати у будь-який час року i на більш тривалий період часу, на відміну від більш молодих груп населення. Значить, доцільно організувати посилені рекламні кампанії для стимулювання попиту цієї групи населення, особливо в період недозавантаження туристських підприємств і в міжсезоння.

При організації анімації, враховуючи особливості, притаманні різним віковим категоріям відпочиваючих на туристичних об'єктах, можна пропонувати такі форми дозвіллєвої діяльності:

Дітям дошкільного віку (допитливим, активним, безпосереднім), провідним типом діяльності яких $\epsilon$ гра, можна запропонувати ігротеки, ранки, казкові подорожі, конкурси малюнків, прогулянки.

Підліткам-школярам поряд 3 перерахованими формами можна пропонувати і інші. Діти цього віку відрізняються досить великою активністю, вимогливістю і навіть прискіпливістю по відношенню не тільки до себе, але й до оточуючих їх людей. Коло інтересів підлітка великий. Це вік романтики та мрії, тому для даної категорії відпочиваючих особливо привабливі походи, романтичні зустpiчi i подорожі. Чим насиченіше життя хлопців у цьому віці, тим вона їм більше подобається. Їм можна пропонувати екскурсії та бесіди, спортивні змагання та змагання юних туристів, конкурси (ерудитів, перукарів, господарочок тощо) i дискотеки, «живі» газети та вікторини, естафети та кільцівки (пісень, віршів, загадок), 
школу ввічливості і лицарські турніри, веселі години і свята.

Для молоді програми дещо змінюються. До цього періоду життя юнаки і дівчата стають фізично зрілими, формуються їхні характери i світогляд. Основними видами діяльності цього періоду є навчання і продуктивна праця, які вимагають великої напруги сил. Але енергії та запалу в цьому віці не позичати, тому в дозвіллєву програму для молодих людей можна включати: КВК, вечори і дискотеки, аукціони, ярмарки та театральні вистави, фестивалі та шоу, спартакіади, олімпіади та диспути, походи, а також ігри за типом телевізійних: «Що? Де? Коли?», «Поле чудес», «Розумники і розумниці», «Колесо історії» та ін.

На туристичному ринку для молодих людей існують дві найбільш часто зустрічаються підгрупи: молоді одинаки i молоді сім'ї без дітей. Більшість одинаків - це молоді люди, не обтяжені турботами і витратами на виховання та освіту дітей, які віддають перевагу витрачати свої кошти на відпочинок, подорожі, обіди в ресторанах і на веселе життя. Одиначкам властиві, як правило, високий рівень освіти, прагнення до успіху в професійній діяльності, підвищені вимоги до комфорту і якості життя, індивідуалізм. Вони багато уваги приділяють організації свого вільного часу, прагнучи повною мірою насолоджуватися життям. Молоді самотні люди більше подорожують, порівняно зі своїми ровесниками, які перебувають у шлюбі, і з людьми середнього віку. Вони віддають перевагу активному відпочинку за межами своєї країни чи регіону проживання та користуються для цього послугами авіатранспорту.
Для людей середнього віку, працездатних, які прагнуть відпочити від повсякденної роботи, підійдуть більш спокійні заходи: світські салони та конкурси (краси, гумору, пісень тощо), літературні вітальні та творчі вечори, банкети, презентації та концерти.

Для літніх людей, яким вага частіше хочеться згадати свої молоді роки і вага, що з ними пов'язано, непогано запропонувати такі форми проведення дозвілля, як посиденьки, чаювання, вечори (старовинної музики, романсу, спогадів). У цьому віці накопичено вже великий життєвий досвід, придбані безцінні навики, якими люди цього покоління прагнуть поділитися 3 молоддю, тому представляється доречним запропонувати їм показати свою майстерність (вироби), наприклад, на виставках рукоділля.

Пропоновані гостям види i форми дозвілля повинні бути психологічно виправдані. Людям, які займаються активними формами роботи 3 великим фізичним навантаженням, буде корисний відпочинок, що знімає напругу, втому, стресовий стан. Для тих, хто веде сидячий спосіб життя, страждає від гіподинамії, потрібні на відпочинку зарядка i активізація. Крім того, людина повинна отримувати від дозвілля і моральне задоволення. Тому, щоб правильно скласти програму відпочинку, необхідно знати, як людина вважає за краще проводити своє дозвілля.

Особливу увагу необхідно приділити сімейному дозвіллю, який виконує відновну функцію сім'ї, тобто має на меті відновлення та підтримання здоров'я, задоволення різних духовних потреб. Сімейні туристи 
відвідують готелі в будь-який час року. Сімейні пари (люди у віці від 35 до 54 років) воліють витрачати гроші на подорожі та розваги. Більшість людей цього віку добре освічені. Пріоритетним для них є самовдосконалення. Отримання нової інформації вони вважають необхідним засобом розширення кругозору. Задоволення потреб цієї групи - важливий фактор для подальшого успішного розвитку туристичного комплексу.

Добре організувати роботу анімаційної служби можна тільки за наявності достатньої матеріальної бази. Для проведення шоу-програм, спортивних ігор та інших розважальних заходів необхідні відповідне устаткування і реквізит. Оскільки відпочинок кожен розуміє по-своєму, то й пропозиція повинна бути різноманітного. Чим багатше матеріальна база, тим більша кількість розваг можна запропонувати.

Матеріальна база для анімаційних програм повинна включати:

- обладнання для відпочинку на пляжі (водні атракціони, башти вільного падіння, парасолі, гірки, човни тощо);

- обладнання для дитячих майданчиків (гойдалки, каруселі, альтанки, гірки, ігрові та пневматичні атракціони, оформлювальні фігури у вигляді казкових персонажів, надувні карнавальні костюми тощо);

- приміщення, меблі і необхідний реквізит і інвентар для міні-клубу (різні настільні ігри, фарби, книжкирозмальовки, пластилін, пазли, набори формочок, ляльки, машинки, кольоровий папір, олівці тощо);

- обладнання для рухливих ігор і тренажерних залів (спортивні тренажери, екстремальні атракціони, мішені, аксесуари для пейнтбол, бадмінтону, футболу тощо);

- приміщення, книги та меблі для бібліотеки;

- приміщення та інвентар для станцій і пунктів прокату човнів, водних велосипедів, лиж і пр.;

- приміщення, амфітеатр або обладнаний майданчик на відкритому повітрі для проведення масових заходів та розважальних шоу;

- обладнання, декорації і набір костюмів і реквізиту для сцени;

- проекційне, звукове, сценічне, світлотехнічне та інше обладнання для проведення шоу, дискотек, конкурсів і змагань;

- ігрові автомати;

- обладнання та приміщення для більярду, боулінгу, казино (якщо останні передбачені).

Щоб запропонувати туристу повну анімаційну програму, курортні або клубні готелі повинні мати особливу інфраструктуру та великі можливості (тенісні корти, баскетбольні, волейбольні та інші спортивні та ігрові майданчики, паркові атракціони, віндсерфінг, човни, акваланги, басейни, аквапарки, пляжні бари, таверни, кінотеатри, дискотеки, нічні клуби, боулінг-центри, більярдні, казино, тоталізатори і т.д.). Дизайн цих об'єктів вимагає особливої уваги.

Розглянувши стан дозвіллєвої сфери в сучасній Україні можна зауважити, що, з одного боку, відбувається усвідомлення важливості розвитку дозвіллєвого простору з метою самовдосконалення особистості через туристичну сферу, з іншого, - понині залишаються невирішеними суттєві проблеми (недосконалість інфраструктури, споживацька спрямованість дозвілля, стримування іннова- 
цій), які гальмують не тільки іiі розвиток, але й відбиваються на процесі формування соціальних суб'єктів.

Висновки та перспективи подальших досліджень. Індустрія гостинності розвивається швидкими темпами завдяки соціальному, економічному i політичному прогресу та завдяки тому, що кількість подорожуючих суттєво збільшилася. 3 метою підвищення конкурентоздатності і прибутку, підприємства готельного господарства намагаються запроваджувати нові прогресивні форми обслуговування та організовувати відпочинок, дозвілля і розваги. Дозвілля, розваги, як і праця, є невід'ємними складовими життєдіяльності людини. Розважаючись, людина чи група людей задовольняють свої духовні потреби, оцінюють свої можливості. Відпочивати та розважаючись можна як у природному, так i штучному середовищі. Створення відповідних умов для цього і $є$ завданням індустрії розваг.

Індустрія розваг - це молода галузь, яка формує i розвиває особистість, впливає на виховання, формування оптимістичного настрою, відпочинок, культурний розвиток людини тощо. Поняття дозвілля, відпочинок у великому тлумачному словнику подаються як синоніми в означені часу вільного від праці, якоїсь дiï.

Анімаційна діяльність у сфері туризму $\epsilon$ невід'ємною частиною дозвіллєвої діяльності соціуму взагалі і окремої людини зокрема. Слід зазначити, що анімаційна діяльність $\epsilon$ важливою складовою рекреації, тобто процесу відновлення фізичних і духовних сил організму. Цей процес відбувається в організмі будь-якого 140 туриста, незалежно від того, яким видом туризму він займається. Але деякі види туризму за своєю сутністю вже є рекреаційно-анімаційними (активні форми), інші ж потребують створення анімаційної складової в загальному комплексі рекреаційнотуристичних послуг. До таких напрямів належать, у першу чергу, лікувально-оздоровчий, або рекреаційний туризм. Базою анімаційного процесу тут стають рекреаційно-туристичні заклади: курортні готелі, пансіонати, санаторії, дитячі оздоровчі табори, бази відпочинку, круїзні теплоходи тощо.

Туризм більше, ніж будь-який 3 соціокультурних напрямів діяльності, дає можливість психологічного відходу від звичайної обстановки. Туризм більше, ніж будь-який $з$ соціокультурних напрямів діяльності, дає можливість такого відходу.

Дозвіллєві дії по-справжньому корисні лише тоді, коли дають людям багато позитивних, емоційних вражень. Тому одним 3 основних завдань анімації в туризмі $є$ урізноманітнення спектру анімаційних послуг, диференційований підхід до обслуговування туристів $i$, як результат, створення умов для вільного вибору туристом форм анімаційно-рекреаційної діяльності. Як бачимо, анімація в туризмі є важливим соціально-культурним чинником нашого життя.

Отже, перспективними напрямами подальших досліджень $є$ діагностування дозвіллєвих уподобань різних категорій населення, визначення шляхів мотивації до активного дозвілля, на цій основі планування та реалізація сучасних дозвіллєвих програм та проектів. 


\section{СПИСОК ЛІТЕРАТУРИ}

1. Бабенко Н.Б. Соиіологія вільного часу та дозвілля. К., 2006. 196 с.

2. Бєлєиька І.В. Сучасна соиіокультурна ситуаџія у сфері дозвілля молоді // Вісник Луганського начіонального університету ім. Т. Шевченка. 2010. № 9. C. 71-76.

3. Веденин Ю.А. Динамика территориально-рекреационных систем. К., 1982. C. 260.

4. Гидбут А.В., Мезенцев А.Г. Курортно-рекреационное хозяйство (региональный аспект). М., 1991. С. 94.

5. Добреньков В.И., Кравченко А.И. Фундаментальная сочиология // Бюджет времени и досуг. 2005. Гл. 3. С. 817-851.

6. Зборовский Г.Е. Сочиология досуга и культуры. М., 2006. 245 c.

7. Любічева О.О. Ринок туристичних послуг (геопросторові аспекти). 2002. C. 436.

8. Максимовська Н.О. Сучасний стан дозвіллєвої сфери Украӥни: соиіальнопедагогічний аспект // Вісник Харківської державної академії культури. 2011. Bun. 33. C. 264-272.

9. Михайлова Л.И. Социология культуры // Культура свободного времени и досуга. 2008. Гл. 14. С. 314-336.

10. Муха-Шаек Е. Свободное время и отдых как иенности современной культуры молодежи . 2007. С. 172 .

11. Нельга Т.О. Культура вільного часу: спроба визначення та умови розвитку в сучасному украӥнському суспільстві // Украӥнський соиіум. 2007. № $5 / 6$. C. 37-43.

12. Петрова І.В. Дозвілля в зарубіжних краӥнах. К., 2005. С. 408.

13. Семашко О.М., Піча В.М., Погорілий О.І. та ін. Соиіологія культури. К., 2000. C. 334.

14. Скляр С.Ю. Соціологічний підхід до вивчення дозвілля як соиіального феномену // Сочіологія. 2010. Вип. 133. С. 46-49.

15. Скляр С.Ю. Сочіокультурні трансформачї̈ дозвіллєвого простору молоді в умовах суспільних перетворень в Україні // Соціальні технології. 2010. № 10. C. 206-214.

16. Фоменко Н.В. Рекреаційні ресурси та курортологія . К., 2007. С. 312.

17. Цимбалюк Н.М. Інституціональні зміни в культурно-дозвіллєвій діяльності. Культурно-дозвіллєва сфера Украӥни: динаміка змін та перетворень. К.,2004. C. 14-25.

18. Цимбалюк Н. М. Дозвілля в Украӥні. Теоретичні та емпіричні. К., 2003. C. 224.

19. Цимбалюк Н.М. Соціологія дозвілля. К., 2001. С. 180. 
20. Штомпка П. Социология // Время в обществе. 2012. Гл. 21. С. 493-512.

21. Щерба Г.І. Формування духовних иінностей молоді, організаиія дозвілля $i$ відпочинку як складова молодіжної політики в Украӥні // Украӥнський соиіум. 2008. № 1. C. 103-111.

22. Ядранський Д.М. Соџіологія вільного часу, як складова соиіології праиі // Грані. 2010. № 2 (70). С. 114-117.

\section{REFERENCES}

1. Babenko, N.B. (2006). Sotsiolohiia vilnoho chasu ta dozvillia [Sociology of free time and leisure]. Kiev, 196. [in Ukrainian].

2. Beletskaya, I.V. (2010). Suchasna sotsiokulturna sytuatsiia u sferi dozvillia molodi [The current socio-cultural situation in the field of youth leisure]. Visnyk Luhanskoho natsionalnoho universytetu im. T. Shevchenka - Bulletin of Luhansk National University. T. Shevchenko Kiev, 71-76 [in Ukrainian].

3. Vedenin, U.A. (1982). Dinamika territorialno-rekreatsionnykh sistem [Dynamics of territorial-recreational systems]. Moskva, 260. [in Russian].

4. Gidbut, A.V., Mezentsev, A.G. (1991). Kurortno-rekreatsionnoe khozyaistvo (regionalnyi aspekt). [Resort and recreational economy (regional aspect)], Moskva, 94. [in Russian].

5. Dobrenkov, V.I. (2005). Fundamentalnaya sotsiologiya [Fundamental sociology]. Byudzhet vremeni i dosug - Time and leisure budget, Moskva, 817851. [in Russian].

6. Zborovsky, G.E. (2006). Sotsiologiya dosuga i kultury [Sociology of leisure and culture]. Sverdlovsk, 245. [in Russian].

7. Lyubitseva, O.O. (2002). Rinok turistichnikh poslug (geoprostorovi aspekti) [Market of tourist services (geospatial aspects)], 436. [in Ukrainian].

8. Maksymovska, N.O. (2011). Suchasnii stan dozvillevoï sferi Ukraïni: sotsialnopedagogichnii aspekt [The current state of the leisure sphere of Ukraine: social-pedagogical aspect]. Visnik Kharkivskoï derzhavnoï akademiï kulturiBulletin of the Kharkiv State Academy of Culture, Kharkov, 264-272. [in Ukrainian].

9. Mikhailova, L.I. (2008). Sotsiologiya kultury [Sociology of culture]. Kultura svobodnogo vremeni i dosuga - Culture of free time and leisure, Moskva, 314-336. [in Russian].

10. Mukha-Shaek, E. (2007). Svobodnoe vremya i otdykh kak tsennosti sovremennoi kultury molodezhi [Free time and rest as values of modern youth culture], Odessa-Lviv, 172. [in Russian].

11. Nelga, T.O. (2007). Kultura vilnogo chasu: sproba viznachennya ta umovi rozvitku $v$ suchasnomu ukraïnskomu suspilstvi [Culture of free time: an attempt 
to determine and conditions of development in modern]. Ukraïnskii sotsium Ukrainian society. Kiev, 37-43. [in Ukrainian].

12. Petrova, I.V. (2005). Dozvillya v zarubizhnikh kraïnakh [Leisure in foreign countries], 408. [in Ukrainian].

13. Semashko, O.M., Picha, V.M., Pogoriliy, O.I. and others. (2000). Sotsiologiya kulturi [Sociology of culture], 334. [in Ukrainian].

14. Sklyar, S.Y. (2010). Sotsiologichnii pidkhid do vivchennya dozvillya yak sotsialnogo fenomenu [Sociological approach to the study of leisure as a social phenomenon]. Sotsiologiya - Scientific works. Nikolaev, 46-49. [in Ukrainian].

15. Sklyar, S.Y. (2010). Sotsiokulturni transformatsiï dozvillevogo prostoru molodi $v$ umovakh suspilnikh peretvoren $v$ Ukraïni [Socio-cultural transformations of leisure space of youth in conditions of social transformations in Ukraine]. Sotsialni tekhnologiï - Social technologies. Nikolaev, 206-214. [in Ukrainian].

16. Fomenko, N.V. (2007). Rekreatsiini resursi ta kurortologiya [Recreational resources and balneology], 312. [in Ukrainian].

17. Tsymbalyuk, N.M. (2004). Institutsionalni zmini v kulturno-dozvillevii diyalnosti. Kulturno-dozvilleva sfera Ukraïni: dinamika zmin ta peretvoren Institutional changes in cultural and leisure activities [Cultural and leisure sphere of Ukraine: dynamics of changes and transformations]. Kiïvskii derzhavnii institut kulturi - Kyiv State Institute of Culture. Kharkov, 14-25. [in Ukrainian].

18. Tsymbalyuk, N.M. (2003). Dozvillya v Ukraïni. Teoretichni ta empirichni [Leisure in Ukraine. Theoretical and empirical aspects]. Kï̈skii derzhavnii institut kulturi - Kyiv State Institute of Culture. Kharkov, 224. [in Ukrainian].

19. Tsymbalyuk, N.M. (2001). Sotsiologiya dozvillya [Sociology of leisure]. Kharkov, 180 [in Ukrainian].

20. Shtompka, P. (2012). Sotsiologiya [Sociology].Vremya v obshchestve - Time in society. Warsaw, 493-512. [in Ukrainian].

21. Shcherba, G.I. (2008). Formuvannya dukhovnikh tsinnostei molodi, organizatsiya dozvillya $i$ vidpochinku yak skladova molodizhnoï politiki $v$ Ukraïni [Formation of spiritual values of youth, organization of leisure and recreation as a component of youth policy in Ukraine]. Ukraïnskii sotsium Ukrainian society, 103-111. [in Ukrainian].

22. Yadransky, D.M. (2010). Sotsiolohiia vilnoho chasu, yak skladova sotsiolohii pratsi [Sociology of free time as a component of the sociology of labor]. Hrani - Faces. Dnipropetrovsk, 114-117. [in Ukrainian].

Стаття надійшла до редакиії 11.09.2021

Посилання на статтю: Назаренко О.В. Соціологічний аспект організації дозвілля в Україні // Розвиток методів управління та господарювання на транспорті: Зб. наук. праць, 2021. № 3 (76). C. 129-144. DOI 10.31375/2226-1915-2021-3-129-144. 
DEVELOPMENT OF MANAGEMENT

AND ENTREPRENEURSHIP METHODS

ON TRANSPORT, № 3 (76), 2021
РОЗВИТОК МЕТОДІВ

УПРАВЛІННЯ ТА ГОСПОДАРЮВАННЯ

НА ТРАНСПОРТІ, № 3 (76), 2021

Article received 11.09.2021

Reference a JournalArtic: Nazarenko, Olga V. (2021). Sociological aspect of organizing leisure time in Ukraine. Development of management and entrepreneurship methods on transport. 3 (76), 129-144. DOI 10.31375/2226-1915-2021-3-129-144. 